\title{
Time series analysis of the ISEW at the local (regional) level: method and intent
}

\author{
F. Ciampalini, R. Ridolfi, F. M. Pulselli \& N. Marchettini \\ Department of Chemical and Biosystems Sciences, University of Siena, \\ Siena, Italy
}

\begin{abstract}
This paper presents a time series analysis of the Index of Sustainable Economic Welfare (ISEW). It is a measure, alternative to GDP, that in accordance with the principles of sustainability takes into consideration environmental and social aspects within the traditional economic accounting system. The Index is calculated for an Italian Province from 1971 to 2003 and it will be compared with the provincial GDP during the same period. A growing gap between the two monetary values (GPI grows faster then ISEW) has been occurring consistently with the national trend. This means that part of the wealth which GDP asserts does not correspond to welfare. The ISEW monetizes this gap in order to orient decisions for a more sustainable way of life and more correct policies.
\end{abstract}

Keywords: GDP, ISEW, welfare, sustainability, ecological economics.

\section{Introduction}

This paper represents one of the many examples, in this case an ecological economics initiative, where it's possible to find a political planning where economy and ecology speak the same language and rely on the research and university for building their future society in which the unique development to wish is the sustainable one. Ecological Economics offers this potential because it is built around a more complex understanding of human society that transcends the traditional economic vision [1].

The economic system is an open subsystem of a larger but finite and nongrowing ecosystem; so no infinite economic growth is possible in a finite world. Society is nowadays moving from a relatively empty world to a relatively full world, and an exclusive emphasis on economic growth could produce serious, and possibly irreversible, ecological damages. 
Now, it is easy to understand the necessity of a shift from the growth model to the development one. The process of economic development could improve people's standard of living not only in monetary terms but also in terms of wellbeing (in the broader sense of quality of life). In brief, GDP is not more the right index to study and plan long term policies, because it tells us only part of the story. On the contrary, it is not possible to have a sustainable development without transparency. GDP is implicitly or explicitly used as a measure of wealth and welfare, of development and progress, of good policy and management. Actually, it was not introduced by Simon Kuznets for measuring welfare.

Its formula ( $\mathrm{GDP}=\mathrm{C}+\mathrm{I}+\mathrm{G}+\mathrm{NX}$ ) represents the value of all final goods and services that are treated via markets. For our purposes, some weaknesses of GDP can be put on evidence: for example, it does not reflect the value of no market goods and services which are, instead, an important part of our welfare; it grows when a forest is cut; it would be higher if a person dies in a hospital than if $\mathrm{s} / \mathrm{he}$ dies at home; car accidents increase GDP; it does not take into consideration household labor. GDP just adds up goods and services produced by the economic system and bought in the market without making a distinction if those market transactions contribute positively or negatively to human welfare.

In 1989, Daly and Cobb proposed the Index of Sustainable Economic Welfare (ISEW) as an alternative measure to the conventional reliance on GDP. It is an indicator of economic welfare, and represents an attempt to measure the underlying economic, social and environmental factors that create real progress. The ISEW represents an important index of underlying long term trends in real welfare. It measures and makes understandable something that is considered important [2] for human well-being and it informs policy-makers and the general public about the factors that affect welfare [3].

Creating awareness at the local level is important. The local (regional or provincial) level often represents the optimal dimension for implementing policies, especially in certain fields. This is mainly due to a major attention paid by local institutions for peculiar problems and to the administrative decentralization [4]. For this reasons, the ISEW has been calculated at the local level, in order to give local authorities a further instrument for taking political decisions consistently with sustainable viewpoint.

This paper shows some results from a time series analysis of ISEW (19712003 ) for the Province of Modena, an Italian province. This is one of the first attempts to perform such a calculation in time series at the local level.

\section{Methods and results}

The ISEW is a measure of economic "performance", alternative to GDP, with the purpose of assessing the level of sustainable welfare of a population living in an area. It takes into account the traditional dimensions of sustainable development, embodying the social, economic and environmental components of well-being. The ISEW is based upon a portion of economic wealth (GDP), relevant to welfare, but various monetary adjustments (additions and subtractions) are made in order to take into account environmental and social items, not currently considered in the GDP framework. 
Table 1: ISEW components and reasons for inclusion/exclusion.

\begin{tabular}{|c|c|c|c|}
\hline & Sign & ISEW components & Reasons for inclusion/exclusion \\
\hline A & & Year & $1971-2003$ \\
\hline B & & $\begin{array}{l}\text { Personal Consumption } \\
\text { Expenditure }\end{array}$ & The basic variable directly affecting economic welfare \\
\hline $\mathrm{C}$ & & $\begin{array}{l}\text { Index of inequality } \\
\text { distribution }\end{array}$ & $\begin{array}{l}\text { Connected to social aspects, it is necessary to have a more } \\
\text { realistic starting point }\end{array}$ \\
\hline $\mathrm{D}$ & & $\begin{array}{l}\text { Weighted Personal } \\
\text { Consumption }\end{array}$ & $\begin{array}{l}\text { The basis to which all other positive and negative } \\
\text { modifications are applied }\end{array}$ \\
\hline $\mathrm{E}$ & + & $\begin{array}{ll}\text { Services } & \text { of } \\
\text { households' labour }\end{array}$ & $\begin{array}{l}\text { An activity outside the market process that however leads to } \\
\text { improvements in welfare }\end{array}$ \\
\hline $\mathrm{F}$ & + & $\begin{array}{l}\text { Consumer durables } \\
\text { services }\end{array}$ & Services connected with goods are benefits \\
\hline $\mathrm{G}$ & + & $\begin{array}{l}\text { Services from Public } \\
\text { Infrastructure }\end{array}$ & $\begin{array}{l}\text { In general people use infrastructures without paying any costs } \\
\text { but in reality lots of money are spent for citizens' welfare }\end{array}$ \\
\hline $\mathrm{H}$ & + & $\begin{array}{l}\text { Public expenditure on } \\
\text { health and education }\end{array}$ & $\begin{array}{l}\text { It is only a portion, the non-defensive one, of public spending } \\
\text { that is expected to add to welfare }\end{array}$ \\
\hline I & - & $\begin{array}{ll}\begin{array}{l}\text { Expenditures } \\
\text { consumer durables }\end{array} & \text { on } \\
\end{array}$ & $\begin{array}{l}\text { They must be subtracted because they are not strictly } \\
\text { connected to welfare, but only the services from them }\end{array}$ \\
\hline $\mathrm{L}$ & - & $\begin{array}{l}\text { Defensive private } \\
\text { expenditures on health } \\
\text { and education }\end{array}$ & $\begin{array}{l}\text { The total value is already present in B or D. Here the defensive } \\
\text { portion, not affecting welfare, is removed }\end{array}$ \\
\hline M & - & $\begin{array}{l}\text { Local advertising } \\
\text { expenditure }\end{array}$ & $\begin{array}{l}\text { This component has been removed from this ISEW exercise } \\
\text { because of the lack data at local level }\end{array}$ \\
\hline $\mathrm{N}$ & - & Cost of commuting & $\begin{array}{l}\text { It is included in the consumption but it is a defensive cost } \\
\text { related to traffic and overcrowding }\end{array}$ \\
\hline $\mathrm{O}$ & - & Cost of urbanization & $\begin{array}{l}\text { Urbanization implies the increase in the price of houses. This } \\
\text { increase in wealth is fictitious then it must not be considered. }\end{array}$ \\
\hline $\mathrm{P}$ & - & Cost of car accidents & $\begin{array}{l}\text { Defensive costs, not related to welfare, that have to be } \\
\text { removed from consumption }\end{array}$ \\
\hline $\begin{array}{l}\text { Q } \\
\text { R, } \\
\text { S }\end{array}$ & - & $\begin{array}{l}\text { Cost of water } \\
\text { pollution } \\
\text { Cost of air pollution } \\
\text { Cost of noise pollution } \\
\end{array}$ & $\begin{array}{l}\text { These costs represent the contribution a society must pay to } \\
\text { solve environmental problems. They are not related to welfare } \\
\text { because defensive. }\end{array}$ \\
\hline $\mathrm{T}$ & - & Loss of wetlands & $\begin{array}{l}\text { Wetlands are important natural habitats, whose protection is } \\
\text { one of the keys of sustainability }\end{array}$ \\
\hline $\mathrm{U}$ & - & $\begin{array}{l}\text { Loss of agricultural } \\
\text { land }\end{array}$ & $\begin{array}{l}\text { Agricultural land is threatened by urbanization and soil } \\
\text { erosion, involving costs that must take into consideration }\end{array}$ \\
\hline $\mathrm{V}$ & - & $\begin{array}{l}\text { Depletion of non } \\
\text { renewable resources }\end{array}$ & $\begin{array}{l}\text { The consumption of non renewable natural capital, undermine } \\
\text { the possibility for future generation to meet their needs }\end{array}$ \\
\hline W & - & $\begin{array}{l}\text { Long-term } \\
\text { environmental damage }\end{array}$ & Long term damages caused by greenhouse gas emissions. \\
\hline $\mathrm{X}$ & + & Net capital growth & $\begin{array}{l}\text { To ensure an economic sustainability, the level of capital per } \\
\text { worker must be maintained. }\end{array}$ \\
\hline $\mathrm{Y}$ & & ISEW & The final value to be compared with the GDP trend \\
\hline
\end{tabular}


The ISEW is roughly defined by the following formula:

ISEW = personal adjusted consumption + non defensive public expenditures defensive private expenditures + capital formation + services from domestic labour - cost of environmental degradation, pollution and damage - cost of depletion of nonrenewable resources

The main works that have been taken as reference points are the ISEW calculations for USA [2], for Italy [5] and for the local level [4].

The following paragraphs will explain each component of the ISEW as shown in Table 1, and their characteristics and trends. Furthermore, some variations with respect to the examples in literature are described too. They are mainly due to the differences between the calculation at the national and the local level. Finally, the resulting trend of the ISEW with respect to GDP is shown.

\subsection{Personal consumption expenditure}

The unique data source available for all the time series analysis was from ISTAT (the Italian institute of statistical analysis). It is a document called "Consumption for Italian families" where it is possible to find the consumption for family o for family's component at regional level, and other several data as shown afterwards. This figure has increased by $54 \%$ from 1971 to 2003 , with an increasing of population nearly $17 \%$.

\subsection{Index of inequality distribution}

The Gini coefficient has been used here. It is a measure of inequality of a distribution, defined as the ratio of the area between the Lorenz curve of the distribution and the curve of the uniform distribution. It is often used as measure of income inequality. Its value can vary from 0 to 1 , where 0 means everyone has the same income, so called "perfect equality"; 1 means that one person owns all the income, that is "perfect inequality". The Gini trend for the Province of Modena shows an improvement in the equal distribution of income, jumping from 0.656 in the 1971 to 0.314 in the 2003 .

\subsection{Weighted personal consumption}

This adjustment is obtained by dividing the consumption expenditure (item $\mathrm{B}$ in table 1 ) by $1+$ Gini coefficient (Fig. 1 ).

\subsection{Services of households' labour}

Following the methodology used for Italy [5], three classes of people have been considered: housewives, unemployed persons and students spend time in housework of 8, 4 and 2 hours/day, respectively, for a total of 330 days/year. ISTAT publishes annual data on working and non-working population, and the price per hour is based on previous studies [4]. Services of households' labour decrease from more than 2,730 millions $€ / 2003$ in 1971 to 1,381 millions $€ / 2003$ in 2003 . 


\subsection{Services from consumer durables}

A positive element of the ISEW are the services from consumer durables (durable goods, cars and houses). The calculation method is the same of Daly and Cobb [6] with a little modification in the percentage assigned to the value of services from a house, which is $5 \%$ instead of $10 \%$.

The final value shows a shift from a nearly thousand million of euros/2003 in 1971 to more than 5 thousand millions of euro/2003 in 2003.

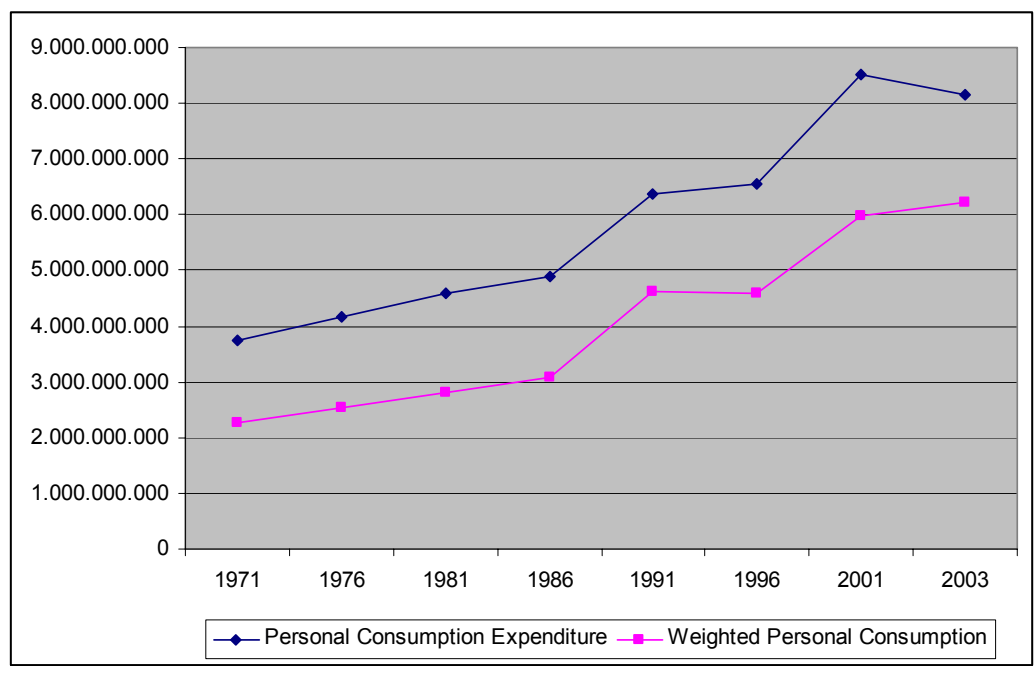

Figure 1: Time series of adjusted consumption for the Province of Modena.

\subsection{Services from public infrastructure}

Daly and Cobb [6] generally exclude government expenditure on public services because they are considered as defensive, with few exceptions. Bad quality roads decrease our welfare for many reasons, such as high maintenance expenditure, more probabilities to have a car accident, etc. Generally, people use the services from the road network without paying, and, in order to embody it in the welfare calculation, this portion of public expenditure must be considered.

This value is not relevant, but it increases from 1,483 thousand of euros/2003 in 1971 to a value of more than 10 millions of euros in 2003 .

\subsection{Public expenditure on health and education}

According to the methodology by Guenno and Tiezzi [5], public expenditure on education are entirely considered as not defensive, whereas the $50 \%$ public expenditure on health are considered as defensive. Hence the $100 \%$ public expenditure on education and the $50 \%$ of public expenditure on health must to be added to Personal Consumption.

This portion of public expenditure was around $€ 822$ millions $(€ / 2003)$ in 1971, and around $€ 973$ millions in 2003. 


\subsection{Expenditures on consumer durables}

The consumption expenditure on durable goods (televisions, personal computers, cars) does not represent the welfare derived from their use. These goods provide utility (and thus welfare) along their life time. This aspect must be counted in the ISEW, so this figure must be subtracted from consumption (note that the services from consumer durables - item $\mathrm{F}$ in tab.1 or Par. 2.5 - are added to consumption). These expenditures were around $€ 343$ millions in $1971(€ / 2003)$ to reach a thousand million euros in 2003.

\subsection{Defensive private expenditures on health and education}

Consumption also includes private expenditures on health and education. According to Daly's work [3], only the $50 \%$ of the total is related to welfare; the rest is defensive (sustained by families not for improving welfare but for restoring or compensating the welfare lost due to modern life-style such as pollution, damages, competitiveness, etc.).

Defensive expenditures on health exceed those for education since 1991, reaching in 2003 a gap of nearly $80 \%$. The total value increases a lot during time, from 88 millions $(€ / 2003)$ in 1971 to 217 millions $€$ in 2003.

\subsection{Local advertising expenditure}

No data on local advertising costs were available, this item was thus omitted.

\subsection{Cost of commuting}

The formula used to value this item is a further development of the ones used by Guenno end Tiezzi [5] and Pulselli et al. [4].

The formula is:

where

$$
\mathrm{C}=0.3 \mathrm{~A}+0.3 \mathrm{~B}+0.3 \mathrm{C}_{1}
$$

0.3 is the estimated portion of the total car use directly related to commuting;

$\mathrm{A}$ is the value of services derived from a car and not its total value;

$\mathrm{B}$ is the expenditure for tickets on public transportation;

$\mathrm{C}_{1}$ is the sum of costs for public and private vehicle maintenance.

The cost of commuting trend increases from $€ 116$ millions $(€ / 2003)$ in 1971 to nearly $€ 440$ millions $€$ in 2003 . This is strictly dependent on the excessive use of car instead of other means of transport, especially in city centers. However, in this case, the value is not so high thanks to the fact that most of the territory is situated on the plain and the use of bicycle is encouraged.

\subsection{Cost of urbanization}

This cost was not considered because, despite buying a house at prices always rising does not produce a correspondent increase in economic welfare, it gives a high level of satisfaction and an equal or greater monetary feedback at the moment of its selling is often assured.

\subsection{Cost of car accidents}

This cost is a part of consumption that is naturally defensive and should be subtracted from the index. The cost of an accident is composed by two factors: 
the personal injury costs which have already been counted among "Defensive private expenditures on health and education" and the non-injury costs. The latter is calculated here, by multiplying the number of car accidents per year by the social costs of an accident.

The trend of this cost is fluctuating and linked to the problem of urban mobility. It is about $€ 7$ millions in 1971 (€/2003), up to 2001-2003 when it reaches about $€ 13$ millions $(€ / 2003)$.

\subsection{Cost of water pollution}

This is an attempt of including environmental aspects within the ISEW framework. In literature, there are several examples to calculate this cost. In this paper, the E.I. (Equivalent Inhabitants) method has been used. The E.I. of the Province of Modena are multiplied by the cost for purifying. Data source for the cost is [4]; E.I. are estimated on the basis of the number of inhabitants, industrial workers and animal productions. The value fluctuates around 70 millions $(€ / 2003)$, reaching its maximum value during the ' 80 s with 88 millions $(€ / 2003)$.

\subsection{Cost of air pollution}

The estimation for this environmental cost is the same of [5] and [4]. Major pollutants are taken into consideration such as $\mathrm{CO}_{2}, \mathrm{NO}_{\mathrm{X}}, \mathrm{SO}_{\mathrm{X}}$ and PM10 and then associated to the abatement cost per ton of emission, taken from [4].

For this figure it seems to be a decrease of all pollutants except $\mathrm{CO}_{2}$.

$\mathrm{SO}_{\mathrm{X}}$ have been decreasing since 1980 because of planning policies adopted by the local government, which decided to move to low environmental impact fuels like methane and discouraged the use of carbon and fuel oil. The cost of air pollution was around $€ 78$ millions $(€ / 2003)$ in 1971 . The highest value was in 1991 (€ 132 millions), while in 2003 it was 90 millions (€/2003).

\subsection{Cost of noise pollution}

There is not so much information to evaluate this item. People are affected from noise in different ways, and there are problems in measuring noise levels on local/national level. The most important source of noise is urban traffic, then the final value was obtained from the relationship between the total number of cars on the provincial territory and an estimation of the value of noise damage produced by a car. The trend of this figure, being strictly connected with territorial car pool, is increasing. It was 18 millions in $1971(€ / 2003)$ and more than 53 millions $(€ / 2003)$ in 2003.

\subsection{Loss of wetlands}

Wetlands are considered to be among the most threatened ecosystems because of their susceptibility to both human and natural stressors. Their importance was highlighted by Daly when he decided to insert them within the ISEW calculation. The variation in wetlands in the Province of Modena was assigned a monetary value according to the paper by Guenno and Tiezzi [5].

The results are positive, meaning that for the Province of Modena there was an increasing in wetlands from 500 hectares in 1971 to 1,470 hectares in 2003. The equivalent monetary value was 6,386 in $1971(€ / 2003)$ and 119,766 in 2003. 


\subsection{Loss of agricultural land}

The economic growth has generated social costs in terms of the loss of farmlands. This adjustment reflects the human colonization of land (road construction or urbanization) and the deterioration of soil quality and erosion (intensive agriculture). The value of this item increases along all the period, from more than 12 millions $(€ / 2003)$ to around 23 millions in 2003. This growing scarcity is due to a bad management of natural capital and it's over exploitation.

\subsection{Depletion of non renewable resources}

El Serafy's formula [8] has been used for the ISEW of the Province of Modena:

$$
R-X=R\left[1 /(1+r)^{n+1}\right]
$$

where:

$\mathrm{X}$ annual income;

$\mathrm{R}$ revenue from extraction net of extraction costs;

$\mathrm{r}$ discount rate;

$\mathrm{n}$ residual life-time of the stock of resources.

The value of this figure is limited to quarry materials and data necessary for finding the final value is related to: type of materials, quantity extracted per year, market prices and extraction costs.

This variable, so important under a sustainability viewpoint, is not so relevant in monetary terms: it was 67 millions in $1971(€ / 2003)$ and 112 millions in 2003. This result is because since the ' 70 s the Province of Modena have been paying attention to the mining industry, aware of all the problems and damages produced by this kind of activity on the surrounding environment.

\subsection{Long-term environmental damage}

The long-term environmental damage is related to the greenhouse gas emissions. We used the calculation method proposed by Daly for USA [6] and we consider all the consumption of fossil fuels, methane and electricity. They are converted in equivalent barrel of oil and multiplied by a tax of 1.9 euro/2003 for each barrel used [7].

This item gives an idea, in monetary terms, of the damage we are producing that will be paid by future generation. For the Province of Modena we calculated a kind of environmental tax of 20 euro/2003 per-capita in 1971, and 50 euro/2003 per-capita in 2003. The monetary value of this item increases from 124 millions in $1971(€ / 2003)$ to more than 324 millions in 2003.

\subsection{Net capital growth}

To ensure an economic sustainability, the level of capital per worker must be maintained. Due to the lack of data it was not possible to use the formula from [5]. Hence, in order to estimate trend, gross fixed investments were used weighted by employed persons in the industrial sector. The trend appears to be 
constant for all the period analyzed, around $€ 1,400$ millions $(€ / 2003)$ with the lowest value in 1986 of about $€ 996$ millions $(€ / 2003)$.

\subsection{ISEW vs. GDP}

A large number of adjustments to consumption base have been done in order to estimate the ISEW. This result can help to understand the criticisms about GDP dealing with its inability to distinguish among transactions which increase or decrease welfare. GDP has to be used only as expression of total business volume, which sums costs and expenditures instead subtracting them. On the contrary, the ISEW methodology aims to make a distinction between positive and negative economic operations. The ISEW, as many said, is not an indicator that shows how far a system is from a sustainable condition, it orients society towards the right direction. Furthermore, the ISEW reflects the influence of policies designed to affect social progress, economic growth, environmental protection and prudent use of natural resources. In doing so, it allows to present a systematic assessment of domestic progress towards sustainable development over long period of time, and to compare this against GDP. Figure 2 shows the comparison between ISEW and GDP for the Province of Modena.

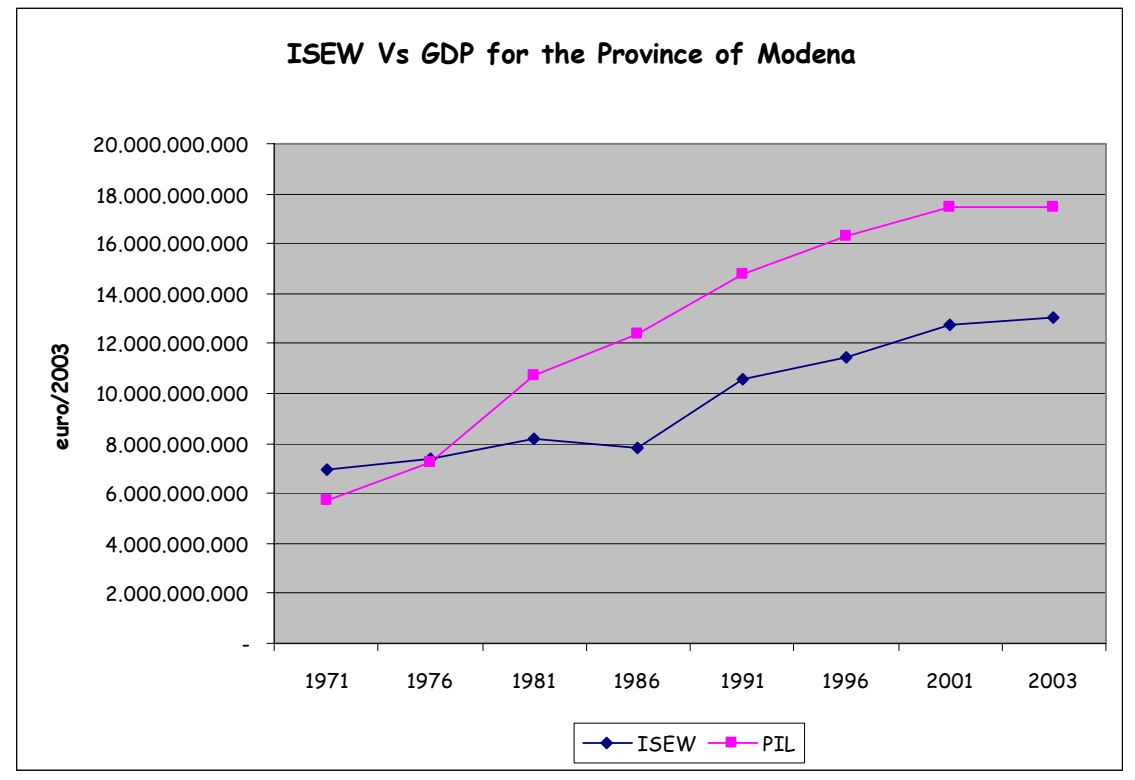

Figure 2: $\quad$ The trend of ISEW and GDP for the Province of Modena.

\section{Conclusion}

The ISEW offers some advantages with respect to other aggregate sustainability indicators:

- $\quad$ it tries to include social and environmental aspects of sustainable development 
- $\quad$ unlike more usual measures of progress, it considers the distribution of resource in a society, and takes into account the treatment of natural capital

- $\quad$ it tries to estimate the net benefits of a society which produces and consumes, showing business people and local leaders the impacts of their activities

- ISEW reflects the influence of policies designed to affect social progress, economic growth, environmental protection and prudent use of natural resources. In doing so, it enables policy and decision makers to present a systematic assessment of domestic progress towards sustainable development over a long period of time, and compares this to GDP.

This paper, from a project in collaboration with the Province of Modena, is an experiment oriented to assess the sustainability at the local level. The assessment of the sustainability of economic and social activities at the local level is certainly a great challenge for local authorities. Their power to take decisions, though regulated by laws, should be put into action on the basis of accurate and comprehensive information. Any decision, plan or project to be implemented should be evaluated both in economic terms and considering social and environmental aspects.

\section{References}

[1] Kysar D.A., Sustainability, distribution and the macroeconomic analysis of Law. Boston College Law review, Vol XLIII No.1, pp. 1-71, December 2001.

[2] Sustainability Indicators for waste, energy and travel for Scotland, Scottish Executive Central Research Unit 2001, Chapter two.

[3] Daly H.E., Cobb, J.B. For the common good: redirecting the economy towards community, the environment, and a sustainable future. Beacon Press, Boston. 482 pp., 1989.

[4] Pulselli et al., The Index of Sustainable Economic Welfare (ISEW) for a Local Authority: A Case Study in Italy. Ecological Economics, in press, 2005.

[5] Guenno G., Tiezzi, S., The Index of Sustainable Economic Welfare (ISEW) for Italy. Worknote 5.98. Fondazione Enrico Mattei, Milano, Italy, 1998.

[6] Daly H.E., Cobb J.B., Un'economia per il bene comune. Il nuovo paradigma economico orientato verso la comunità, l'ambiente e un futuro particolarmente sostenibile. RED edizioni, Como, Italy, 1994.

[7] Anielski, M., Rowe, J., The Genuine Progress Indicator - 1998 update. Redefining Progress. San Francisco, CA, 1999.

[8] El Serafy, S., The proper calculation of income from depletable natural resources. In: Ahmad, Y.J., Serafy, S.E., Lutz, E., (Eds) Environmental Accounting for Sustainable Development. An UNDP-World Bank Symposium, World Bank, Washington, DC. 10-18, 1988. 